\title{
Reshaping local borders in Europe today. A critical reflection founded on an analysis of the case of Finland
}

\begin{abstract}
In Europe, the amalgamation of local authorities is currently used to optimize public resources. Although amalgamation involves several advantages, it needs to fulfil three conditions to be considered successful. First, address local preferences and needs; second, be fair, transparent and accessible to citizens; and third, be a compromise between central and local political elites. In the current paper the fulfilling of these three conditions is analysed using the comprehensive, bottom-up, Finnish reform introduced during the period of 2008-2013. The findings conclude that while the Finnish local reform plan has been successful in reaching a compromise between local and central governments, it has failed insofar as it has not fulfilled the condition of making the process fair, transparent and accessible to citizens. Furthermore, whether the amalgamation has allowed local government to address citizens' preferences and needs in a meaningful and responsive way has yet to be demonstrated.
\end{abstract}

Keywords

Amalgamation • local reform • Finnish local administration • local policy

(C) University of Warsaw - Faculty of Geography and Regional Studies

\author{
Albacete, Xavier ${ }^{1}$, Tort Joan ${ }^{2}$ \\ 'Department of Environmental and Biological Sciences, \\ Environmental Informatics Research Group, \\ University of Eastern Finland, Finland. \\ e-mail: xavier.albacete@uef.fi \\ 2Department of Geography, \\ University of Barcelona, Spain. \\ e-mail: jtort@ub.edu \\ Received: 29 September 2016 \\ Accepted: 28 December 2016
}

\section{Introduction}

The current ongoing economic crisis that is affecting Europe and all levels of its public administration has put the need for optimizing public resources firmly back on the political agenda. One of the ways to achieve this goal is by reforming administrative functions at each level, with particular importance being given to local government as this constitutes the "ground level" for public administration in all countries around the world.

One of the solutions proposed for optimizing public resources, empowering local government and giving it access to larger economies of scale, is that of the amalgamation of local authorities. This optimization of local administrations should, in turn, lead to a more integrated decision-making process for citizens (Vetter \& Kersting 2003). In a detailed analysis of this solution, Swianiewicz (2010) presents seven main arguments in favour of the amalgamation of the municipalities: first, it allows the allocation of more services at the local level; second, local administration can benefit from economies of scale; third, it should help promote local democracy; fourth, it produces fewer income disparities among municipalities; fifth, local governments should be more effective in their planning and in their economic development policies; sixth, it helps reduce the mismatch between administration boundaries and catchment areas of public services; and, finally, it helps promote integration and cooperation within the European Union.

For an amalgamation to be successful, Swianiewicz (2010) reports that the three conditions identified in Paddison (2004) are necessary: first, the reform of the local administration should be able to address local preferences and needs in a meaningful and responsive manner; second, the process of amalgamation should be fair, transparent and accessible to citizens; and, third, the reform should be a compromise between central and local political elites. However, Baldersheim and Rose (2010) warn that larger administrative units will have to handle a more heterogeneous population and, consequently, communication between the citizen and the administration may be more difficult.

The local reform measures implemented in Finland (known by its acronym: PARAS reform) represent a special case. The process was full of ambiguities and not readily classifiable according to any absolute category (Sandberg 2010), likewise the driving factors for the amalgamation are unclear (Askim et al. 2015). Finland's reform was based on a comprehensive, bottom-up reorganization founded on voluntary amalgamations and/or new cooperative arrangements between municipalities was introduced during the period 2008-2013. In the reform, cooperative arrangements have not benefitted from financial rewards whereas amalgamations have (Sandberg 2010).

Today, in 2016, we have sufficient perspective to evaluate the procedure, objectives and outcomes of the Finnish PARAS reform. As such, our research question is: Has local reform in Finland properly addressed the three conditions set out above?

The remainder of this article is organized as follows. In the next section, the Finnish local government is described within the broader European context. This is followed by a description of Finnish local administration and an identification of its reform priorities. In the following section, the main outcomes of the reform are presented. Finally, in the discussion and conclusion sections we evaluate the Finnish local reform and propose further lines of research. 
Finland's local government within the broader European context

Finland's local reform needs to be placed in the broader framework of European local government and its evolution. In this section, we outline the classifications that have been proposed for this tier of government across Europe and summarize their main characteristics.

In Europe, since the second half of the twentieth century, there has been a general tendency towards a reduction in the number of local authorities (Mouritzen 2007; Baccetti 2007; Bäck 2007; Arendsen 2008; Heinelt \& Egner 2008; Martin 2010; Négrier \& Nicolas, 2010; Game, 2012 \& Martín 2013). More specifically, this reduction was especially significant during the 1970 s and again during the early 2000 s. More recently, during the economic crisis, the spotlight has been turned on Europe's local authorities and their capacity to provide more intense services with fewer resources (Bouckaert \& Kuhlmann 2016).

In the Nordic countries, the New Public Management (NPM) has been adopted as the main approach to administrative reform (Balderheim 2003), where NPM can be understood as a way of providing more choices to users and promoting competition between providers so that there is an improvement in service quality. At the same time, the Nordic countries have placed a greater emphasis on promoting management reform strategies and fostering more direct citizen participation than on introducing territorial and functional reforms in local representative democracy (Vetter \& Kersting 2003).

\section{Political power of Europe's urban areas}

In terms of political power in Europe, we review below the jurisdictional structure of local governments in Belgium, France, Italy, Spain, Germany, Denmark and Sweden (Bäck 2007; Négrier \& Nicolas 2010; Baccetti 2007; Heinelt \& Egner 2008; Mouritzen 2007; Burgueño \& Guerrero 2014).

In these countries where municipalities boast a high degree of political and economic independence, exemplified by Belgium and Denmark, responsibilities for health and primary education are assigned to the municipalities. In Sweden, in addition to health and education, local authorities are responsible for industry, agriculture and communications; indeed, all possible functions that could to some extent be assumed by the local level are assigned to the municipalities. Moreover, in these three countries, the municipalities have tax autonomy in order to cover their services.

In the other countries there is no clear defining of functions at this level and, in practice, functions tend to be shared or distributed between different tiers of government. Furthermore, the municipalities have little political autonomy, and thus find themselves under the influence of the state (the case in France), the region (the case in Germany) or both (the case in Spain). Nor do they enjoy financial autonomy as they tend to be economically dependent on regional or central funding.

From the beginning of the 1990s up until the present day, Europe has seen a process of "regionalization" of its administrative functions. If we focus on this "spatial regionalization", the adaptation of municipal borders to the functional level of the region has only taken place over the last few years; however, this process has been implemented simultaneously across Europe.

\section{Finnish local government}

Finland is characterized, above all, by the size of its territory $\left(338,145 \mathrm{~km}^{2}\right)$ and its relatively small population $(5,236,611$ inhabitants). Hence, the country's population density is low compared to that of the EU as a whole (17.6 vs. 114 inhabitants/ $\mathrm{km}^{2}$ ) (Blöchliger \& Vammalle 2012).

However, the nature of population dispersal has changed throughout Finland's history and since the 1990s there has been a tendency towards a depopulation of rural areas combined with a gain in population in the main regional capitals and, especially, in the Helsinki Metropolitan Area (HMA) (Heikkila \& Järvinen 2002; Heikkila 2003; Haapanen 1998 and 2001; Nivalainen 2003; Pekkala 2000 and 1999; Ritsilä \& Haapanen 2003; Ritsilä \& Tervo 1998; Summa et al. 1984; Tervo 2000). These studies reported net flows from rural areas to the main regional centres and to the HMA of people in their early and middle adulthood. Particularly noticeable is the net flow of young adults to the HMA. In contrast, for the elderly population there has been a net flow towards rural areas and regional capitals. However, the combination of these migration dynamics has been the progressive depopulation and ageing of Finland's rural areas and a population gain in regional centres and in the HMA. In addition, Finland is experiencing a general ageing of its population (the percentage of population over the age of 65 stood at $15.6 \%$ in 2003 and is set to rise to $22.8 \%$ by 2020 ). These demographic changes are critical for understanding the need to restructure the country's municipal authorities.

The number of Finnish municipalities has been cut significantly over the last seven decades (from 602 in 1940 to 303 in 2016) (see Figure 1.). However, between 1990 and 2008, the number of municipalities remained relatively stable (between 460 and 415 municipalities, respectively) due to the lack of agreement regarding the need to promote local territorial reforms (Sandberg, 2010). Most of the municipalities have a population between two and ten thousand (200 municipalities), with 48 having a population below two hundred and seven municipalities with more than 100,000 (Figure 1.) (Blöchliger \& Vammalle 2012; Meklin 2010).

In Finland, local government accounts for $30 \%$ of total public sector expenditure and represents two-thirds of public consumption. Under the Finnish Constitution (article 121§), the municipalities are allowed to set local tax levels, while additional income is derived from transfers from the central government, sales revenues and various local charges. The main local public sectors are social welfare and healthcare (which, in normal circumstances, account for up to $50 \%$ of the local budget), education, culture, urban planning, basic services (energy, water and waste management) and basic infrastructure (Blöchliger \& Vammalle 2012; Moisio 2010 and 2012).

Additionally, local administrations are characterised by their considerable functional responsibilities, their high degree of financial self-reliance, their territorial structures and the relatively weak leadership exercised by the mayor (Bouckaert \& Kuhlmann 2016).

\section{Act for the restructuring of local government and services} (PARAS reform)

The political and social conditions in favour of the reform, which was initiated in 2005, were numerous (see Sandberg 2010, for a detailed review). The government's goals in restructuring the

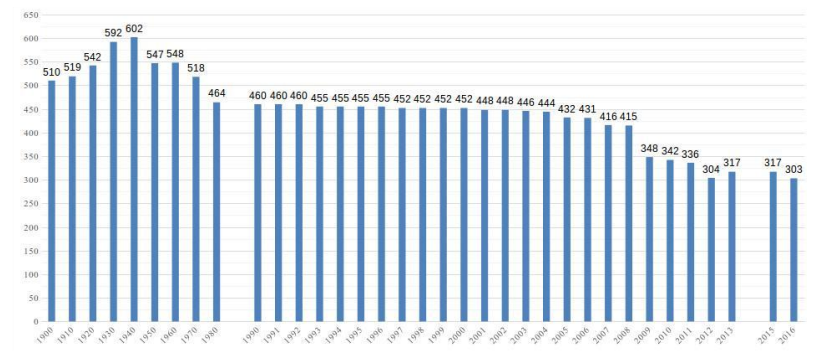

Figure 1. Evolution of the number of municipalities from 1900 to 2009 in Finland. Source: presentation "Finnish Local Government", by AFLRA (The Association of Finnish Local and Regional Authorities), Local and Regional Government Finland, 2011, 2012 
local authorities were twofold: first, to address the demographic challenges; and, second, to guarantee local government finances. The resulting PARAS reform can be divided into three main areas: first, local government structures, where the main goals were the amalgamation of local authorities and the incorporation of parts of some local authorities into other local authorities; second, service structures, where the main goals were to form larger catchment areas for services and thus increase cooperation; and, finally, operational productivity, where the goal was to improve the efficiency of services and operating conditions within the HMA. In the following sections, we detail the reform schedule and goals, specific criteria and other aspects of the reform.

\section{Schedule and goals}

The reform plan was to be introduced between 2005 and 2012 in three main phases. The first phase, May 2005-May 2006, was to be dedicated to collecting detailed information about the current situation and to planning. The second phase, June 2006December 2008, was to focus on decision-making, preparing the execution of the plans and introducing the necessary legislative modifications. Finally, the third phase, January 2009-December 2012, was to be dedicated to executing the plans, with the main role being taken by the local authorities themselves but supervised by central government. The political, economic and social circumstances that facilitated the implementation of the local reform within the political agenda have been identified by Sandberg (2010) as "a window of opportunity" for a government initiative. According to the author, the setting was attributable to the modernization of Finnish society, changes in the political centre of gravity, changes in the representation of local government interests, and changes in the overall strategies of administrative reform.

\section{Specific criteria}

In restructuring the Finnish municipalities, the reform considered the following areas and applied the following main criteria (ALFRA 2012):

1. Primary healthcare. The minimum threshold population for this service was fixed at 20,000 inhabitants. Local authorities were encouraged to reach this target in order to be able to provide primary healthcare themselves.

2. Basic vocational education. The minimum threshold population of 50,000 was fixed in order to be able to operate a centre of this kind.

3. Municipal finances. The reform took into consideration the financial situation of each municipality when studying potential mergers in order to guarantee a town's finances (see the subsection Administrative cooperation for further details).

4. Urban regions. The reform sought to strengthen existing urban areas and to create urban regions with an enhanced economic potential. The original act identified 17 cities and their corresponding regions of influence as economic centres (see Figure 2.) ${ }^{1}$.

\section{Administrative cooperation}

Cooperation between the local authorities was on a voluntary basis, while merging between local authorities was encouraged with the use of amalgamation grants provided by the central government. These grants were designed to cover up to $20 \%$ of total municipal revenues (Moisio 2010). Additionally, local authorities enjoyed fiscal benefits - being excluded from the obligation of having to transfer some of their tax revenues

${ }^{1}$ Of the population, $88 \%(4,690,000$ inhabitants) lives within $50 \mathrm{~km}$ of a city with more than 30,000 residents (Kolehmainen A, New Municipality 2017. Vision of the future of local government, Local and Regional Government Finland).

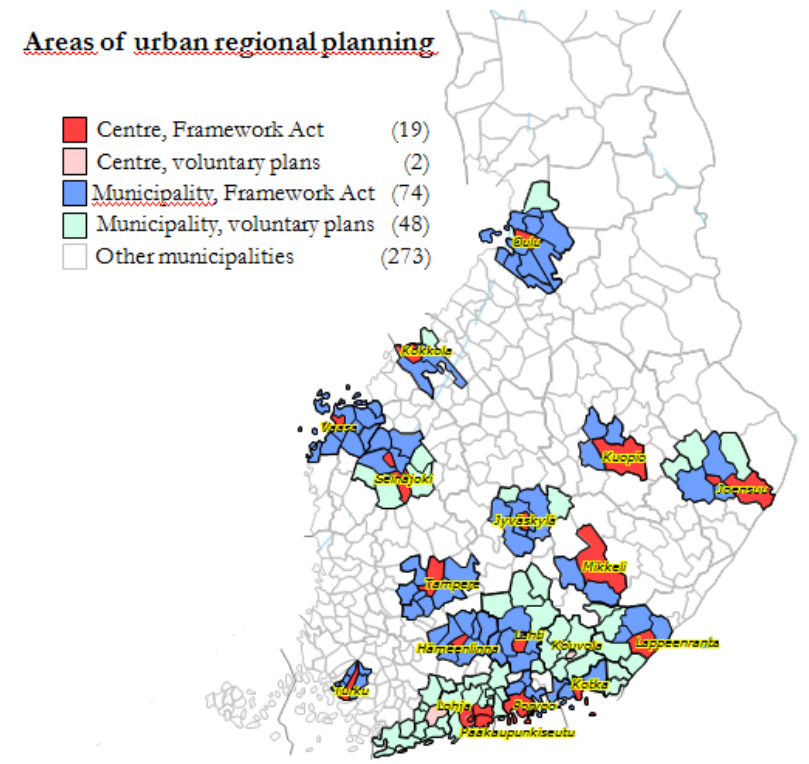

Figure 2. Map of the main urban areas in Finland with some of the negotiations going on. The urban areas are (from north to south): Oulu, Kokkola, Vaasa, Seinäjoki, Kuopio, Joensuu, Jyväskylä, Mikkeli, Tampere, Lahti, Kuovola, Lappenranta, Hämeenlinna, Kotka, Lohja, Turku, Paakaupunkiseutu (Capital Regional Area) and Porvoo (scale 1:100000). Source: presentation "Local government services- organization of service provision: an overview", by AFLRA, 2012

to the national administration for a period of five years (20082012). Before a merger went ahead, the central government was responsible for identifying those local authorities who were at risk of experiencing severe financial difficulties. The criterion applied by the Ministry of Finance was if a municipality's fiscal health was consistently below the country's average, and was also below the limits specified by the central government for two consecutive years, in which case negotiations would be initiated in order to draw up a plan of economic recovery (Moisio 2010).

In those cases where local authorities opted to merge, the act ensured that there would be no lay-offs in personnel for the five years following the merger. This meant that the central government made special grants available for the additional costs generated by the amalgamation process.

Alternatively, local authorities were encouraged to form partnerships in order to reach the population thresholds established for service provision. This could be done by establishing joint municipal authorities, by adopting a host-municipality model (under which one municipality pays another for certain services) or by establishing client-provider arrangements, whereby the public sector enters into agreements with the private sector. With the exception of belonging to a hospital district, which is compulsory for all municipalities, cooperation is voluntary. Joint authorities that provide social and healthcare do not receive State grants but are financed by the municipalities themselves (Moisio 2010). In planning their actions the local authorities had to present a project by June 2007 that forecasted its impact on service provision for 2015 and 2025 . These new dates represented the second phase in the implementation of the reform.

Parallel aspects of reform

1. Health system: The problematic restructuring of the Finland's municipal map has shifted discussion towards 
MISCELLANEA GEOGRAPHICA - REGIONAL STUDIES ON DEVELOPMENT

the need to re-define the regions for health services not affected by the local reform. As we have seen, healthcare is one of the services that all municipalities must provide (on their own or co-hosted with other municipalities). The current health system comprises 237 health centres (58 of which are the so-called joint health centre federations) and 20 hospital districts (with a catchment population ranging from 65,000 to 1.4 million inhabitants). However, only $23 \%$ of these health centres comply with the minimum threshold established under the reform for this service. Yet, among the strategic projects proposed to the central government by the municipalities in 2007 , there were plans to create 70 co-operational regions, involving some 300 municipalities, for the provision of primary health services.

In the public debate, certain political and social sectors that were opposed to local reform lobbied solely for the restructuring of the health system.

2. Voting effects: Although Moisio (2012) has shown that municipal mergers have had no effect on the number of votes that parties receive, one of the main arguments against the process is related to voter representation in the municipalities, since the representation of the smaller municipalities has been proportionally reduced.

3. Cultural background: The act has been largely sensitive to the cultural elements that make up present-day Finland. For example, the directives have been flexible in their application in the autonomous region of the Åland Islands. The proposed merger has sought to join those areas where Swedish is the main language, in order to guarantee linguistic rights and to implement cost controls when offering the municipal services (Blöchliger \& Vammalle 2012).

4. Educational centres: The main goal here has been to increase the size of education centres as larger schools can cater to more specialist needs (Moisio 2010). However, once a school becomes large enough to accommodate 200 to 250 pupils, it becomes increasingly difficult for cooperating municipalities to derive any further financial benefits.

\section{Reform priorities}

Local reforms have been classified on the basis of multiple variables. In Table 1, we present the levels of priority for the Finnish local reform as proposed by Bouckaert and Kuhlmann (2016).

\section{Reform outcomes}

Despite all the possibilities afforded by the act, a number of reports have pointed out potential problems arising from its application (Blöchliger \& Vammalle 2012). First, it did not provide for the fact that mergers could be completed with larger municipalities. As a result, municipalities with financial problems tended to form amalgamations (encouraged by the fact that central grant guaranteed no lay-offs for the five years following the merger). Second, the joint provision of services can be applied by adopting different combinations of municipalities for each service. Thus, the provision of services (and the associated bureaucracy), far from being simplified, ended up becoming much more complex. Third, the central government has had to start enforcing cooperation among those areas that are not financially balanced.

The main advantages have been a significant reduction in the number of authorities and service centres. For example, healthcare administrative areas have fallen from 237 to the current 121 , while it is planned that the administrators of basic vocational education will be rationalised from 30 to just 3 or 4 . In total, 253 municipalities have created partnerships, establishing 67 partnership areas, while the overall number of municipalities has fallen from 415 to 342 .

Table 1. Evaluation of the level of priorities for the reform (extracted from Bouckaert and Kuhlmann, in Kuhlmann and Bouckaert, 2016).

\begin{tabular}{|l|c|}
\hline OBJECTIVES & \multicolumn{1}{|c|}{$\begin{array}{c}\text { High } \\
\text { importance }\end{array}$} \\
\hline Improving input efficiency & $\begin{array}{c}\text { Medium } \\
\text { importance }\end{array}$ \\
\hline More specialized staff & $\begin{array}{c}\text { High } \\
\text { importance }\end{array}$ \\
\hline Improving output / Improving service quality & $\begin{array}{c}\text { High } \\
\text { importance }\end{array}$ \\
\hline Improving room for manoeuvring \\
Evolution / Delegation of powers
\end{tabular}

\section{PATTERNS OF CONFLICTS}

\begin{tabular}{|l|c|}
\hline Central - Local & $\begin{array}{c}\text { High } \\
\text { importance }\end{array}$ \\
\hline Rich - Poor & $\begin{array}{c}\text { Medium } \\
\text { importance }\end{array}$ \\
\hline Large - Small & $\begin{array}{c}\text { Medium } \\
\text { importance }\end{array}$ \\
\hline Left - Right & No importance \\
\hline Technocracy - Politics & $\begin{array}{c}\text { High } \\
\text { importance }\end{array}$ \\
\hline
\end{tabular}

PROBLEMS DURING THE AMALGAMATION PROCESS

\begin{tabular}{|l|c|}
\hline Strong opposition by politicians & $\begin{array}{c}\text { High } \\
\text { importance }\end{array}$ \\
\hline Strong opposition by employees & No importance \\
\hline $\begin{array}{l}\text { Insufficient resources for reform } \\
\text { implementation }\end{array}$ & $\begin{array}{c}\text { Medium } \\
\text { importance }\end{array}$ \\
\hline No time to prepare the implementation & $\begin{array}{c}\text { Medium } \\
\text { importance }\end{array}$ \\
\hline $\begin{array}{l}\text { Other reform projects happening at the same } \\
\text { time }\end{array}$ & $\begin{array}{c}\text { High } \\
\text { importance }\end{array}$ \\
\hline Unclear/Inconsistent reform objectives & $\begin{array}{c}\text { High } \\
\text { importance }\end{array}$ \\
\hline OUTCOME OF AMALGAMATIONS &
\end{tabular}

\begin{tabular}{|c|c|}
\hline \multicolumn{2}{|l|}{ Improving input } \\
\hline Cost savings & $\begin{array}{c}\text { Medium } \\
\text { importance }\end{array}$ \\
\hline \multicolumn{2}{|l|}{ Improved output } \\
\hline Improved professional quality & $\begin{array}{c}\text { High } \\
\text { importance }\end{array}$ \\
\hline Improved legal correctness & No importance \\
\hline Improved citizen orientation & No importance \\
\hline More equal treatment of citizens & $\begin{array}{c}\text { Medium } \\
\text { importance }\end{array}$ \\
\hline \multicolumn{2}{|l|}{ Room for manoeuvring } \\
\hline Strengthened local autonomy & $\begin{array}{c}\text { Medium } \\
\text { importance }\end{array}$ \\
\hline $\begin{array}{l}\text { Increased influence of the superordinate tier } \\
\text { of government. Strengthened local mayors/ } \\
\text { executives }\end{array}$ & $\begin{array}{c}\text { Medium } \\
\text { importance }\end{array}$ \\
\hline Strengthened local citizenship & No importance \\
\hline
\end{tabular}


In order to implement the reform, three main potential conflicts had to be avoided: those within the cabinet; those between the government and the opposition; and those between conflicting municipal interests. All three of these were avoided by, respectively, internal agreement; a governmental coalition of parties who had historically opposed the reform; and the creation of ALFRA, a discussion platform for municipalities (Sandberg 2010).

\section{Discussion}

The act for restructuring local government and services (the PARAS reform) has, it is claimed, been a success for five main reasons (Blöchliger \& Vammalle 2012). First, a previous consensus was reached on the need for reform and on the fact that the municipal level should be responsible for the provision of public services. Second, the negotiation phase took place during a period of strong economic growth (2005-2007). Third, the subsidies were scaled for time and population so that the sooner the merger took place and the greater the number of inhabitants involved, the greater the financial reward for the merging municipalities. Fourth, the Ministry of the Interior took the political initiative in favour of the municipal mergers. And fifth, the PARAS reform was implemented by working groups in which most of the parties were represented so that continuity was ensured despite a potential change of the party in power.

In general, the experience has shown that the larger municipalities tend to prefer mergers because of the potential benefits that smaller municipalities can provide them with, whereas the smaller municipalities, afraid of losing their identity, tend to prefer co-operation. This finding is in line with claims made by Sandberg (2010) to the effect that the voluntary organisation between municipalities may have increased the asymmetry between them, and that the need for reform has not necessarily matched the speed at which the amalgamations and co-operations have taken place.

If we look now at the three necessary conditions reported by Swianiewicz (2010) to ensure successful reform, it can be seen that the performance of the PARAS reform has been somewhat mixed. The condition that a compromise should be reached between local and central political elites would seem to have been met by the establishment of the ALFRA platform and the political procedures that were adopted. However, in ensuring that the process was fair, transparent and accessible to the citizens, the current reform must be judged unsuccessful given its failure to hand any real democratic power to the citizens for deciding on the amalgamation or cooperative arrangements, with all the criteria having being previously established by government. As can be seen in Table 1., the main focus of the reform was on economic and functional optimization, while the participatory mechanisms under the new administrative structure were not really considered. Finally, any conclusions concerning the third condition, that is, the need for the amalgamation to address the preferences and needs in a responsive manner, remain unclear for the time being. Contrary, therefore, to the claims of success made by Blöchliger and Vammalle (2012), two key features remain as yet unresolved and prevent us from providing a wholly positive evaluation. First, as Sandberg (2010) argues, the voluntary nature of the reform has increased the asymmetry between municipalities. This asymmetry could well exacerbate economic imbalances and so create even greater differences in the provision of services. And, second, as Lassen and Serritzlew (2011) point out, the increase in the size of the municipalities may undermine present levels of internal political efficacy, especially if considered in the light of the 2007 structural reform carried out in neighbouring Denmark.

\section{Conclusions}

The current paper has analysed the Finnish restructuring of local government and services (the PARAS reform). To do so, we have examined both the social and urban structure of the country, analysed the reform measures and compared the reform criteria and outcomes with the necessary conditions for success as reported by Swianiewicz (2010). Our study concludes that while the Finnish local reform plan has been successful in reaching a compromise between local and central governments, it has failed insofar as it has not fulfilled the condition of making the process fair, transparent and accessible to the citizens. Furthermore, whether the initiated amalgamation allows local government to address citizen preferences and needs in a meaningful and responsive way has yet to be demonstrated.

The PARAS reform is based on amalgamations and cooperative arrangements, which in turn have depended on the criteria proposed by central government and debated with the local administrations. The provision of real autonomy for local government and the guarantee of fiscal protection during the years in which the process was being completed have enabled different local authorities to merge in accordance with their preferences and, therefore, any potential conflicts have been minimized.

The Finnish case is, moreover, a successful example of the implementation of local reform and one that highlights the need to rationalize municipal territorial structures. In this regard, we would stress, among other points of interest, the improved efficiency achieved in the management of a number of public services and the use of benchmarks (set after careful research) to establish the highest possible balances when promoting the merging of municipalities and encouraging administrative cooperation.

However, a number of question marks remain regarding the future asymmetries of local government and the degree of local democracy and participation that the PARAS reform has achieved. Regarding the former, future research needs to evaluate the quality of all services offered across the municipalities following the reform. As for the latter, systems of electronic participation (now being implemented) need to be carefully assessed in future studies in order to assess the impact of the reform on the communication between the local authorities and their citizens.

\section{Acknowledgements}

The authors would like to thank Mr. Daniel Clarke and Mr. lain K. Robinson for their improvement of the text. This research was founded by the Government of Catalonia (2014SGR825); and the Ministerio de Economía y Competividad, Spanish Government (CSO2015-65787-C6-4-P).

\section{References}

ALFRA (The Association of Finnish Local and Regional Authorities) (n.d.). Local government services - organisation of service provision: an overview.

ALFRA (The Association of Finnish Local and Regional Authorities) \& Tyler Sutton, Public Sector Digest (2011). Restructuring Local Government in Finland.

Arendsen, G 2008, 'Els nivells intermedis de govern als Països Baixos. Un debat permanent', Col/lecció Estudis. Sèrie Govern Local, 9 edn, Diputació de Barcelona, Barcelona.
Bacetti, C 2007, 'Itàlia: la província', Col·lecció Estudis. Sèrie Govern Local 3 edn, Diputació de Barcelona, Barcelona.

Baldersheim, H 2003, 'Local government reforms in the Nordic countries. Bringing politics back in?' in Reforming Local Government in Europe: Closing the gap between democracy and efficiency eds N Kersting \& A Vetter, Opladen: Springer Fachmedien Wiesbaden, pp. 29-38.

Baldersheim, H \& Rose, L (eds.), 2010, Territorial choice. The politics of boundaries and borders, Palgrave-Macmillan, London. 
Blöchliger, H \& Vammalle, C 2012, Finland: Restructuring local government and services. Reforming Fiscal Federalism and Local Government: Beyond the Zero-Sum Game. OECD.

Bouckaert, G \& Kuhlmann, S 2016, 'Introduction: Comparing local public sector reforms: Institutional policies in context', in Local public sector reforms in times of crisis national trajectories and international comparisons, eds S Kuhlmann \& G Bouckaert, Palgrave-Macmillan, London, pp. 1-22. DOI 10.1057/978-1-137-52548-2

Burgueño, J \& Guerrero, M 2014, 'El mapa municipal de España. Una caracterización geográfica', Boletín de la Asociación de Geógrafos Españoles, no. 64, pp. 11-36.

Bäck, H 2007, 'Suècia: les autoritats del nivell regional abocades a l'abolició o al renaixement', Col·lecció Estudis. Sèrie Govern Local, 4 edn, Diputació de Barcelona, Barcelona.

Game, C. 2012, 'La modernitzaió del govern local al Regne Unit', Col·lecció Estudis. Sèrie Govern Local, 22 edn, Diputació de Barcelona, Barcelona.

Haapanen, M. 1998, 'Internal migration and labour market transitions of unemployed workers' in VATT-Discussion papers edn. Helsinki: Valtion taloudellinen tutkimuskeskus. Government Institute for Economic Research.

Haapanen, M 2001, Labour migration and wages, School of Business and Economics, University of Jyväskylä.

Heikkila, E 2003, 'Differential urbanisation in Finland', Tijdschrift voor Economische en Sociale Geografie, vol. 94, no. 1, pp. 49-63.

Heikkila, E \& Järvinen, T 2002, 'Past, present and future of urbanization in Finland' in International Textbook of Urban Systems: Studies of Urbanization and Migration in Advanced and Developing Countries, ed. Gloucester: Edward Elgar, Edward Elgar Publishing, pp. 241.

Heinelt H \& Egner, B 2008, 'Els comtats alemanys', Col.lecció Estudis. Sèrie Govern Local 12 edn, Diputació de Barcelona, Barcelona.

Kersting N, Caulfield J, Nickson A, Olowu D \& Wollmann, H 2009, Local governance reform in global perspective, VS Verlag für Sosialwissenschaften, Wiesbaden.

Martin, S 2010, 'Els consells de comtat a Anglaterra', Col.lecció Estudis, Sèrie Govern Local 15 ed., Diputació de Barcelona, Barcelona.

Kolehmainen, A (n.d.).New municipality 2017. Vision of the future of local government.

Lassen, D \& Serritzlew, S 2011, 'Jurisdiction size and local democracy: Evidence on internal political efficacy from large-scale municipal reform', American Political Science Review, vol. 105(2), pp. 238-58.

Meklin, P 2010, 'Municipalities measured. Evaluation of the initial situation and development potential of local authorities participating in the reform'. Evaluation Research Programme ARTTU Studies, no. 4. Acta Plus Publication.
Moisio, A 2010, VATT Publications 56: Local public sector in transition, A Nordic perspective, no. 56, Valtion taloudellinen tutkimuskeskus, Government Institute for Economic Research, Helsinki.

Moisio, A 2012, VATT publications 61: Rethinking local government: Essays on municipal reform, no. 61, Valtion taloudellinen tutkimuskeskus. Government Institute of Economic Research, Helsinki.

Mouritzen, PE 2007, 'Reformar el Govern Local a Dinamarca: Com i per què?' Col/lecció Estudis. Sèrie Govern Local, 2 edn., Diputació de Barcelona, Barcelona.

Négrier, E \& Nicolas, F 2010, 'El departament: una institució de la República Francesa', Col·lecció Estudis: Sèrie Govern Local, 18 edn., Diputació de Barcelona, Barcelona.

Nivalainen, S 2003, 'Who move to rural areas? Micro evidence from Finland', ERSA 2003, Jyväskylä, Finland.

Pekkala, S 1999, 'Migration and individual earnings in Finland: a regional perspective', European Regional Science Association Conference 1999, Dublin, Ireland.

Pekkala, S 2000, 'Migration in a core - periphery model: analysis of agglomeration in regional growth centres', 40th Congress of The European Regional Science Association 2000, Barcelona, Spain.

Ritsilä, J \& Haapanen, M 2003, 'Where do the highly educated migrate? Micro-level evidence from Finland', International Review of Applied Economics, vol.17, no. 4, pp. 437-448.

Ritsilä, J \& Tervo, H 1998, 'Regional differences in migratory behaviour in Finland', 37th Congress of the European Regional Science Association 1998, Vienna, Austria.

Sandsberg, S (ed.) 2010, 'Finnish power-shift: the defeat of the periphery?' in Territorial Choice: The politics of boundaries and borders, eds $\mathrm{H}$ Baldersheim \& LE. Rose, Palgrave Macmillan, London, pp. 42-60.

Summa, H, Valkonen, T \& Martelin, T 1984, 'Migration and intraurban residential mobility in the Helsinki Metropolitan Area', IIASA Workshop on Dynamics of Metropolitan Areas 1984, Rotterdam, Netherlands.

Swianiewicz, P (ed.) 2010, Territorial consolidation reforms in Europe. Local government and public service reform initiative, Open Society Institute. Budapest, Hungary.

Tervo, H 2000, 'Migration and labour market adjustment: Empirical evidence from Finland 1985-90', International Review of Applied Economics, vol. 14, no. 3, pp. 343-360.

Vetter, A \& Kersting, N 2003, 'Reforming local government. Heading for efficiency and democracy', in Reforming local government in Europe: Closing the gap between democracy and efficiency, eds N Kersting \& A Vetter, Opladen: Springer Fachmedien Wiesbaden, pp. 333-349. 